\title{
Research on the mechanical properties of concrete stub column under axial compression loading with square steel tube self- compacting iron tailing
}

\author{
Yuan Xi WANG ${ }^{1}$, Xi Kai DU ${ }^{1, *}$, and Jing Hong LIU² \\ ${ }^{1}$ Urban and Construction College, Hebei Agricultural University, Baoding 071001, China \\ ${ }^{2}$ School of Civil Engineering, TCU, Tianjin, 300384, China
}

\begin{abstract}
In this paper, the influence of steel rate and substitution rate of iron tailing powder on the bearing capacity of the stub columns is mainly investigated through the test of five concrete stub columns under axial compression loading with square steel tube self-compacting iron tailing, and the test bearing capacity is compared with the bearing capacity calculated by each code. The test results show that the bearing capacity of the test piece increases obviously with the increase of the steel content; the bearing capacity of the test piece is less affected by the substitution rate of iron tailing powder; it is suggested to use code GB50936-2014 to design and calculate the bearing capacity of the stub column under axial compression loading.
\end{abstract}

\section{Introduction}

The progress of society and development of mineral resources is closely related to the utilization. The random disposal and accumulation of tailings and destruction of surface vegetation have a serious impact on the natural environment [1]. A certain fineness of iron tailing powder is used as mineral admixture in concrete, so that the concrete can achieve good workability and durability [2]. Due to its high fluidity and filling property, selfcompacting concrete is closely combined with steel tube wall, and achieves better interaction in the use stage. Scholars all over the world have made some achievements in the research of self-compacting concrete filled steel tubes, such as Han Linhai [3], Li Yi [4], etc., but there are few researches on self-compacting iron tailing concrete filled steel tubes. In this paper, on the basis of fixed amount of fly ash, taking the different substitution rate and steel rate of iron tailing powder replacing fly ash as variables, the stub column axial compression test of square steel tube self-compacting iron tailing concrete is carried out.

\section{General situation of the test}

\subsection{Design and manufacture of test piece}

Five concrete stub columns under axial compression loading with square steel tube self-compacting iron tailing are designed and manufactured in the test. The main variables of substitution rate $(0 \%, 50 \%, 100 \%)$ and steel content rate $(0.12,0.17,0.22)$ of iron tailing powder are used in the test. The detailed parameters of the test piece are shown in Table 1.

Table 1 Parameter table of axial compression test piece

\begin{tabular}{cccccccc}
\hline $\begin{array}{c}\text { The } \\
\text { serial } \\
\text { numbers }\end{array}$ & $\begin{array}{c}\mathrm{B} / \mathrm{m} \\
\mathrm{m}\end{array}$ & $\begin{array}{c}\mathrm{t} / \mathrm{m} \\
\mathrm{m}\end{array}$ & $\begin{array}{c}\mathrm{L} / \mathrm{m} \\
\mathrm{m}\end{array}$ & $\mathrm{r} / \%$ & $\begin{array}{c}\alpha / \\
\%\end{array}$ & $\xi$ & $\begin{array}{c}\mathrm{Nu} / \\
\mathrm{kN}\end{array}$ \\
\hline A-R1-T2 & 100 & 3.8 & 300 & 0 & 17 & 1.43 & 997 \\
A-R2-T2 & 100 & 3.8 & 300 & 50 & 17 & 1.49 & 976 \\
A-R3-T2 & 100 & 3.8 & 300 & 100 & 17 & 1.53 & 770 \\
A-R3-T1 & 100 & 2.78 & 300 & 10 & 13 & 1.1 & 913 \\
A-R3-T3 & 100 & 4.73 & 300 & 100 & 22 & 1.84 & 1056 \\
\hline
\end{tabular}

Note: B-side length of test piece, t-wall thickness of steel tube, L-height of test piece, r-substitution rate of iron tailing powder, a-steel content rate, $\xi$-casing hoop steel coefficient, R1, R2, R3 respectively represent substitution rate of iron tailing powder of $0 \%, 50 \%$, $100 \%$; T1, T2, T3 respectively represent wall thickness of steel tube of $2.78,3.80,4.73 \mathrm{~mm}$, Nu-ultimate bearing capacity of test piece. 


\subsection{Material properties of test piece}

Q235 straight seam welded square steel tube is selected as the steel. See Table 2 for detailed results of material properties of steel.

Table 2 Mechanical parameters of steels

\begin{tabular}{ccccc}
\hline $\begin{array}{c}\text { wall } \\
\text { thicknesst/mm }\end{array}$ & $\begin{array}{c}\text { Yield strength } \\
\text { fy/MPa }\end{array}$ & $\begin{array}{c}\text { Tensile strength } \\
\text { fu/MPa }\end{array}$ & $\begin{array}{c}\text { Modulus of elasticity } \\
\text { Es/GPa }\end{array}$ & Poisson's ratio \\
\hline 2.78 & 388.36 & 421.96 & 218.16 & 0.24 \\
3.80 & 321.64 & 419.54 & 215.47 & 0.33 \\
4.73 & 357.85 & 393.57 & 208.19 & 0.43 \\
\hline
\end{tabular}

Jidong brand P.O 42.5R grade cement, natural river sand, ordinary tap water are used as core concrete. The coarse aggregate is $5 \sim 20 \mathrm{~mm}$ continuous graded iron tailed ore, the admixture is secondary fly ash, iron tailed ore powder with specific surface area of $750 \mathrm{~m}^{2} / \mathrm{kg}$, and polycarboxylic acid superplasticizer. The mix proportion and measured strength of self-compacting iron tailings concrete are shown in Table 3.

Table 3 The mix proportion and measured strength of self-compacting iron tailings concrete

\begin{tabular}{|c|c|c|c|c|c|c|c|c|c|c|}
\hline \multirow[b]{2}{*}{$\begin{array}{l}\text { Substitution } \\
\text { rate } / \%\end{array}$} & \multirow[b]{2}{*}{$\begin{array}{c}\text { Water } \\
\text { binder } \\
\text { ratio }\end{array}$} & \multicolumn{7}{|c|}{ Mix proportion/ $\left(\mathrm{kg} / \mathrm{m}^{-3}\right)$} & \multirow[b]{2}{*}{$\begin{array}{l}\text { fcu } \\
/ \mathrm{MPa}\end{array}$} & \multirow{2}{*}{$\begin{array}{c}\mathrm{Ec} \\
/ \mathrm{MPa}\end{array}$} \\
\hline & & Cement & $\begin{array}{l}\text { Iron tailed } \\
\text { ore }\end{array}$ & Water & Sand & $\begin{array}{l}\text { Fly } \\
\text { ash }\end{array}$ & $\begin{array}{l}\text { Iron tailed } \\
\text { ore powder }\end{array}$ & $\begin{array}{l}\text { Water } \\
\text { reducing } \\
\text { agent }\end{array}$ & & \\
\hline 0 & 0.38 & 376 & 871 & 204 & 721 & 162 & 0 & 2.145 & 55.8 & 38374 \\
\hline 50 & 0.38 & 376 & 871 & 204 & 721 & 81 & 81 & 2.357 & 52.3 & 36327 \\
\hline 100 & 0.38 & 376 & 871 & 204 & 721 & 0 & 162 & 2.469 & 48.9 & 34118 \\
\hline
\end{tabular}

\subsection{Loading scheme and data measurement}

The $2000 \mathrm{kN}$ press is used for loading test, and the loading device is shown in Fig. 1 (a). The test is carried out in the way of grading loading. The load of each stage is $1 / 10$ of the estimated bearing capacity of the test piece. When the load reaches $90 \%$ of the estimated bearing capacity of the test piece, the displacement control loading is adopted, and the holding speed is $1 \mathrm{~mm} / \mathrm{min}$. When the test piece is damaged rapidly or the load is reduced to $85 \%$ of the ultimate bearing capacity, the test is finished.

The strain gauge is arranged in the middle of the steel tube wall except for the weld side, and the transverse strain and longitudinal strain of the test piece are measured during the loading process. The arrangement of test points and loading device of the test piece are shown in Fig. 1 (b).
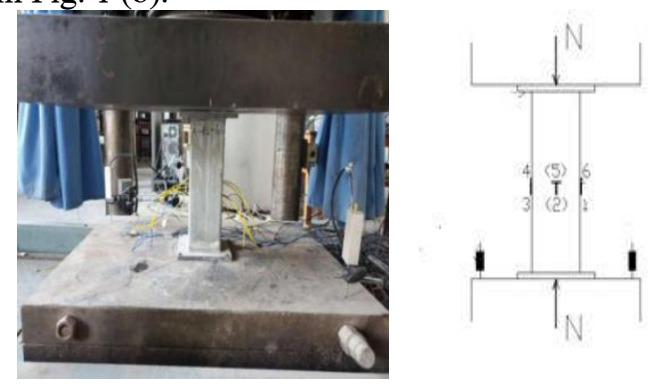

Fig. 1 Loading device of the test piece

\section{Test results and analysis}

\subsection{Test phenomenon}

At the initial stage of loading, the load is small, and the test piece is in a stable state without obvious deformation in appearance; when the load reaches about $80 \% \sim 90 \%$ of the estimated bearing capacity, there is a slight swell in the middle of the test piece, accompanied by a small sound of concrete being crushed; when the test piece reaches the ultimate load, the swell in the middle of the test piece develops rapidly, the sound of concrete being crushed is obvious, and the test piece is in the plastic stage. When the load is reduced to $85 \%$ of the ultimate bearing capacity of the test piece, a new oblique ring swell appears in the middle and upper part of some test pieces. The failure mode of the test piece is shear failure, and the core concrete is crushed finally, which belongs to plastic failure. See Fig. 2 for the final failure mode of the test piece. The serial numbers of the test pieces from left to right are A-R1-T2, A-R3-T1, A-R3-T2, A-R3-T3, AR2-T2.

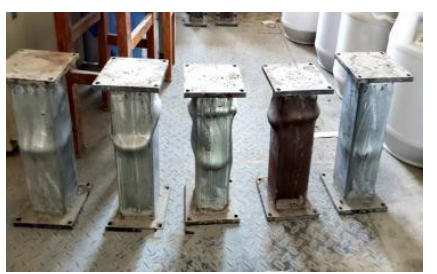

Fig. 2 Failure mode of axial compression test piece

\subsection{Bearing capacity analysis of test piece}

Draw the influence curve of each parameter on the bearing capacity of the test piece according to the test data in Table 1. From Fig. 3 (a), it can be seen that with the increase of steel content, the axial compression bearing capacity $\mathrm{Nu}$ of the test piece increases from 
$770 \mathrm{Kn}$ to $1056 \mathrm{Kn}$, with an increase range of $18.57 \%$ $37.14 \%$. The influence of steel content on the axial compression bearing capacity of the test piece is significant. With the increase of the steel content of the test piece, the restraint effect of the steel tube on the core concrete increases, and the bearing capacity of the core concrete increases, so the axial compression bearing capacity of the test piece increases. It can be seen from Fig. 3 (b) that with the increase of the substitution rate of iron tailing powder, the axial bearing capacity $\mathrm{Nu}$ of the test piece decreases from $997 \mathrm{Kn}$ to $913 \mathrm{Kn}$, with a decrease range of $2.1 \% \sim 8.4 \%$. The results show that the substitution rate of iron tailing powder has little effect on the axial compression bearing capacity of the test pieces. The main reason for the decrease of the axial compression bearing capacity of the test pieces is that the strength of the core concrete decreases with the increase of the substitution rate of iron tailing powder.

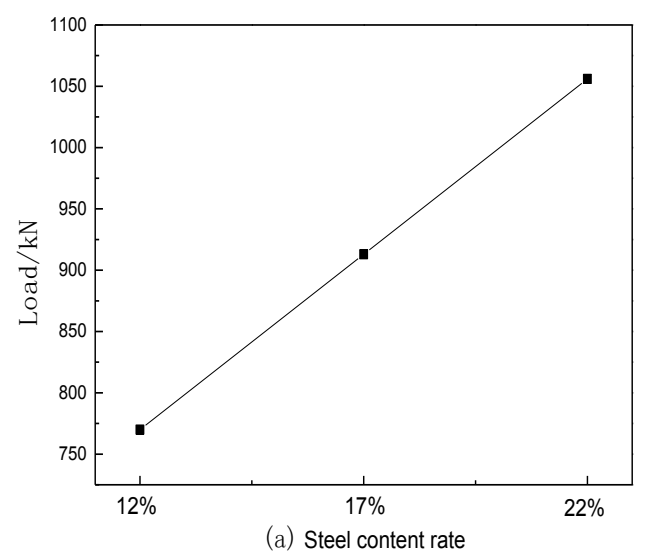

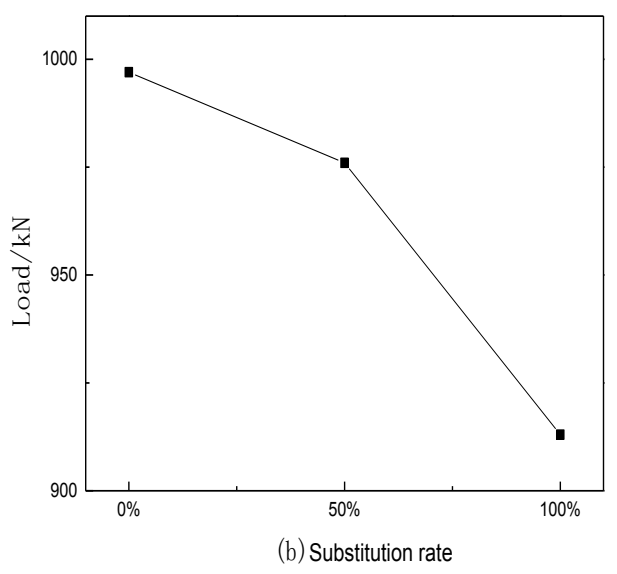

Fig. 3 Influence of various parameters on bearing capacity of test piece

\subsection{Comparative analysis of bearing capacity of test piece}

The design theory of bearing capacity of ordinary concrete-filled steel tube can be divided into superposition theory and unified theory. In this paper, BS5400 (2005), AISC (2005) and GB50936-2014, GJB4142-2000 and DBJ13-51-2003 [5], which are based on the superposition theory, are applied to calculate the bearing capacity of concrete filled steel tube, and are compared with the actual bearing capacity $\mathrm{Nu}$ of the test piece. See Table 4 for detailed data.

Table 4 Comparative analysis of test value and calculation value of bearing capacity of axial compression specimen

\begin{tabular}{|c|c|c|c|c|c|c|c|c|c|c|c|}
\hline \multirow{2}{*}{ The serial numbers } & \multirow{2}{*}{$\mathrm{Nu} / \mathrm{kN}$} & \multicolumn{2}{|c|}{ GB 50936-2014 } & \multicolumn{2}{|c|}{ DBJ 13-51-2003 } & \multicolumn{2}{|c|}{ GJB 4142-2000 } & \multicolumn{2}{|c|}{ AISC (2005) } & \multicolumn{2}{|c|}{ BS 5400(2005) } \\
\hline & & $\mathrm{N} / \mathrm{kN}$ & $\mathrm{Nu} / \mathrm{N}$ & $\mathrm{N} / \mathrm{kN}$ & $\mathrm{Nu} / \mathrm{N}$ & $\mathrm{N} / \mathrm{kN}$ & $\mathrm{Nu} / \mathrm{N}$ & $\mathrm{N} / \mathrm{kN}$ & $\mathrm{Nu} / \mathrm{N}$ & $\mathrm{N} / \mathrm{kN}$ & $\mathrm{Nu} / \mathrm{N}$ \\
\hline A-R1-T2 & 708 & 615 & 1.032 & 1081 & 0.923 & 1013 & 0.985 & 1355 & 0.736 & 633 & 1.575 \\
\hline A-R2-T2 & 513 & 452 & 1.031 & 1062 & 0.919 & 995 & 0.981 & 1342 & 0.720 & 621 & 1.571 \\
\hline A-R3-T1 & 648 & 605 & 0.898 & 903 & 0.853 & 896 & 0.859 & 1104 & 0.574 & 524 & 1.471 \\
\hline A-R3-T2 & 799 & 635 & 0.970 & 1057 & 0.864 & 990 & 0.922 & 1338 & 0.827 & 633 & 1.443 \\
\hline A-R3-T3 & 556 & 471 & 1.083 & 1168 & 0.904 & 1030 & 1.025 & 1481 & 0.789 & 730 & 1.446 \\
\hline Average value & - & - & 1.003 & - & 0.892 & - & 0.955 & - & 0.729 & - & 1.501 \\
\hline Standard deviation & - & - & 0.071 & - & 0.032 & - & 0.065 & - & 0.097 & - & 0.067 \\
\hline $\begin{array}{l}\text { Coefficient of } \\
\text { variation }\end{array}$ & - & - & 0.071 & - & 0.036 & - & 0.068 & - & 0.133 & - & 0.044 \\
\hline
\end{tabular}

From table 4, it can be seen that the average ratio of the actual bearing capacity of the test piece to the bearing capacity of the test piece calculated in accordance with GB50936-2014 is 1.003, the coefficient of variation is 0.071 , and the result has little discreteness. Therefore, it is recommended to use GB50936-2014 code to calculate the bearing capacity of self-compacting concrete stub columns with square steel tube iron tailings under axial compression. 


\section{Conclusion}

(1) The failure mode of the concrete stub column with the self-compacting iron tailing of square steel tube under axial compression is plastic failure. With the increase of the substitution rate of iron tailing powder, the location of the local swell of the test pieces is transferred from the middle to the upper part. With the increase of the steel content, the serious swell occurs in the upper and middle parts of the test pieces.

(2) The steel content of the test piece is the main factor affecting the bearing capacity of the test piece. The steel content of the test piece increases from $12 \%$ to $22 \%$, and the maximum increase of the bearing capacity of the test piece is $37.1 \%$. The substitution rate of iron tailing powder has little effect on the mechanical properties of the test pieces. When the substitution rate of iron tailing powder increases from 0 to $100 \%$, the bearing capacity of the test piece decreases.

(3) Five kinds of concrete-filled steel tube codes are compared and analyzed. The average rate of the actual bearing capacity of the test piece to the bearing capacity of the test piece calculated according to GB50936-2014 is 1.003 , and the coefficient of variation is 0.071 . The results are of small discreteness. It is recommended to use this code to calculate the bearing capacity of the concrete stub column under axial compression loading with square steel tube self-compacting iron tailing.

\section{Acknowledgement}

1.Subsidized Project of Innovative Ability Training for Postgraduates in Hebei Provincial Education Department (CXZZSS2019058).

2.Educational Commission of Hebei Province of China (ZD2019117).

\section{References}

1. Y.L.Chen, Y.M Zhang, T.J. Chen. Metal Mine.162(2009).

2. X.Y.Zhang, Q.Song, H.Li, et al.B CHIN CERAM SOC.32.2559.(2013).

3. L.H.Han,G.H.Yao,X.L.Zhao.JCSR.61.1241.(2005)

4. Y.Li, X.L.Tang.J Archit Civil En.26(2008).

5. N.D.Hu, X.K.Du, P.Y.Liu, et al.J Build Sturc.37.36.(2016) 